\title{
EXPERIMENTAL INVESTIGATION FOR THE OPTIMIZATION OF THE WEDM PROCESS PARAMETERS TO OBTAIN THE MINIMUM SURFACE ROUGHNESS OF THE Al 7075 ALUMINIUM ALLOY EMPLOYED WITH A ZINC-COATED WIRE USING RSM AND GA
}

\author{
EKSPERIMENTALNA RAZISKAVA OPTIMIZACIJE PROCESNIH \\ PARAMETROV ŽIČNE EROZIJE S CINKOM OPLAŠČENE Cu ŽICE \\ ZA ZAGOTOVITEV MINIMALNE POVRŠINSKE HRAPAVOSTI \\ Al ZLITINE 7075 Z UPORABO POSTOPKOV RSM IN GA
}

\author{
Shanthi Jayachandran ${ }^{*}$, Mohan Raman², Thangavelu Ramasamy ${ }^{3}$ \\ ${ }^{1}$ Renovation and Modernisation Division, Mettur Thermal Power Station-I, Mettur -636406, Tamilnadu, India \\ 2Department of Mechanical Engineering, Sona College of Technology, Salem-636005, Tamilnadu, India \\ ${ }^{3}$ Renovation and Modernisation Division, Mettur Thermal Power Station-I, Mettur-636406, Tamilnadu, India
}

Prejem rokopisa - received: 2018-07-28; sprejem za objavo - accepted for publication: 2018-12-17

doi:10.17222/mit.2018.166

\begin{abstract}
Wire Electrical Discharge Machining (WEDM) is widely used for machining conductive materials of intricate, complex and challenging shapes in the field of aerospace, die and mould making, automobile industries and the medical field. Proper selection of the WEDM process parameters can give good responses. Out of the various process responses, to achieve the minimum surface roughness is very difficult, due to arcing by the electrical discharge. The present investigation has been made to optimize the process parameters of WEDM during machining the Al 7075 aluminium alloy with zinc-coated copper wire using the Response Surface Methodology (RSM). Four input process parameters of WEDM, i.e., Pulse On Time, Pulse Off Time, Wire Feed and Wire Tension, were chosen as the process variables to study the process performance and to obtain the minimum surface roughness. An analysis of variance (ANOVA) was carried out to study the effect of the process parameters on the surface roughness and a mathematical model was developed. The model has been verified and checked for adequacy. The best fit surface roughness $\left(R_{\mathrm{a}}\right)$ value predicted is $1.048 \mu \mathrm{m}$ for a Pulse On $\left(T_{\mathrm{ON}}\right)$ value of $120 \mu \mathrm{sec}$, a Pulse Off $\left(T_{\mathrm{OFF}}\right)$ value of 58 usec, a Wire Feed $(W F)$ of $3 \mathrm{~m} / \mathrm{min}$ and a Wire Tension $(W T)$ value of $9 \mathrm{gm}$. Furthermore, it is observed that with an increase in the pulse-on time the Surface Roughness also increases, and an increase in the pulse-off time and the wire tension, the Surface Roughness decreases. Wire Feed does not influence much on the Surface Roughness.

Keywords:WEDM (Wire Electrical Discharge Machining), optimisation, surface roughness, RSM, GA, Al 7075
\end{abstract}

Žična erozija (WEDM; angl.: Wire Electrical Discharge Machining) se pogosto uporablja za obdelavo in rezanje kompleksno oblikovanih izdelkov, modelov in orodij iz prevodnih materialov v letalski, orodjarski, modelarski in avtomobilski industriji ter v zdravstvu. Pri tem postopku je zelo pomembna izbira ustreznih procesnih parametrov WEDM. Doseganje minimalne površinske hrapavosti reza je zelo zahtevno zaradi nastajajočega talilnega obloka med razelektrevanjem. Avtorji so optimizirali procesne parametre WEDM, ki uporablja s cinkom oplaščeno bakreno žico med mehansko obdelavo Al zlitine $7075 \mathrm{z}$ uporabo metodologije odgovora površine (RSM, angl.: Response Surface Methodology). Izbrali so štiri vhodne procesne parametre WEDM, in sicer: čas vklopa $\left(T_{\mathrm{ON}}\right)$ in izklopa $\left(T_{\mathrm{OFF}}\right)$ električnega impulza, hitrost dovajanja žice $W F$ in napetost žice $W T$ kot spremenljivke za študij vpliva procesa na zagotovitev minimalne hrapavosti. Z analizo variance (ANOVA) so raziskovali vpliv procesnih parametrov na površinsko hrapavost in na njeni osnovi razvili matematični model. Model so verificirali in preizkusili njegovo ustreznost. Najboljše ujemanje vrednosti za površinsko hrapavost $\left(R_{\mathrm{a}}\right)$ je bilo $1,048 \mu \mathrm{m}$ pri $T_{\mathrm{ON}}$ vrednosti $120 \mu$ sec, $T_{\mathrm{OFF}}$ vrednosti $58 \mu \mathrm{sec}$, hitrosti dovajanja žice $W F 3 \mathrm{~m} / \mathrm{min}$ ter napetosti žice $W T 9 \mathrm{mN} / \mathrm{m}$. Avtorji ugotavljajo, da se je z nadaljnjim podaljševanjem časa $T_{\mathrm{ON}}$ povečevala površinska hrapavost. S podaljševanjem časa $T_{\mathrm{OFF}}$ in povečevanjem napetosti žice pa se je površinska hrapavost zmanjševala. Hitrost dovajanja žice ni pomembno vplivala na površinsko hrapavost.

Ključne besede: WEDM - žična erozija, optimizacija, površinska hrapavost, RSM, GA, Al zlitina 7075

\section{INTRODUCTION}

Several researchers investigated the different aspects of WEDM, but no comprehensive research work has been reported so far in the field of wire electrical discharge machining of this Al 7075 alloy using zinc-coated copper wire. Hence, an attempt was made to explore the influences of selected variable process parameters.

*Corresponding author e-mail:

shanthi_jc@yahoo.com (Shanthi Jayachandran)
G. E. Totten and D. S. Mackenzie ${ }^{1}$ reported the machinability ratings of aluminium alloys span into five groups, with ratings of $\mathrm{A}, \mathrm{B}, \mathrm{C}, \mathrm{D}$ and $\mathrm{E}$, which are ordered in increasing order of chip length and decreasing order of surface quality. The Al 5083 aluminium alloy ranked D is an indicator for poor machinability. WEDM is one of the latest machining techniques to process the Al 5083 aluminium alloy to any complex intricate shapes with high accuracy and precision when comparing with diamond-based cutting tools. J. Prohaszka et al. ${ }^{2}$ investigated the effect of electrode material coating with zinc, tin and magnesium on machinability in the WEDM pro- 
cess. These coating materials are required for improving the cutting efficiency because the existing wires do not fulfill all the requirements. R. Chalisgaonkar and J. $\mathrm{Kumar}^{3}$ explored the characteristics of pure titanium during rough cut operation, and after the finish cut operation, they revealed the microstructure analysis of zinccoated and in the uncoated wires the erosion during the rough cut operation was found to be more than the finish cut. B. Sivaraman et al. ${ }^{4}$ stated that in the WEDM process the Taguchi method is most ideal and suitable, it simplifies the optimisation of multiple performance characteristics by avoiding complicated mathematical computations. G. Selvakumar et al. ${ }^{5}$ presented an optimum input-parameter combination for the minimum $\mathrm{Ra}$ and the maximum MRR was obtained by an analysis of the signal-to-noise $(\mathrm{S} / \mathrm{N})$ ratio and the process was optimized by a Pareto-optimality approach by machining the Al 5083 aluminium alloy. D. Siva Prasad et al. ${ }^{6}$ investigated the effect of different WEDM process parameters on the damping behavior of the A 356.2 aluminum alloy. The damping capacity of this alloy increases with an increase in the frequency and increasing Pulse On.

A. Dey et al. $^{7}$ examined the machinability of the cenosphere fly-ash reinforced $\mathrm{Al} 6061$ aluminium alloys for various combinations of the input process parameters. The optimal combination of process parameters was arrived at for the maximum MRR, the minimum Tool Wear Rate and the minimum $\mathrm{R}_{\mathrm{a}}$. K. H. Ho et al. ${ }^{8}$ carried out the WEDM process by understanding the interrelationship between the various factors affecting the process and identified the optimal machining condition from the infinite number of combinations. The adaptive monitoring and control systems were implemented to tame the transient WEDM behaviour without the risk of wire breakages. S. Kuriakose and M. S. Shunmugam ${ }^{9}$ investigated the optimal parameters of the WEDM process for improving the cutting performance. There is no single optimal combination of cutting parameters, as their influences on the cutting velocity and the surface finish are quite the opposite. In the present work, a multiple regression model is used to represent the relationship between the input and output variables and a multi-objective optimization method based on a Non-Dominated Sorting Genetic Algorithm (NSGA) is used to optimize the WEDM process.

A. Sharma et al. ${ }^{10}$ made an attempt to machine an $\mathrm{Al}$ 6063 / ZrSiO4(p) (5 \%) metal-matrix composite using WEDM. The objective was to investigate the influence of the process parameters, i.e., $T_{\mathrm{ON}}, T_{\mathrm{OFF}}$, Peak Current and $\mathrm{SV}$ on the Cutting Rate and found experimentally that increasing the $\mathrm{T}_{\mathrm{ON}}$ and Peak current, the cutting rate increases, whereas increasing the $T_{\mathrm{OFF}}$ and $\mathrm{SV}$ decreases the cutting rate. The higher discharge energy associated with the increased $T_{\mathrm{ON}}$, Peak Current and lesser TOFF and SV leads to more powerful explosions, which increase the cutting rate. H. C. Tsai et al. ${ }^{11}$ investigated the electrode performance and revealed that wires generally used are of brass or copper with a diameter of about $0.3-0.5 \mathrm{~mm}$, but in recent times coated wires are widely used, usually zinc coated over brass wire. The impacts of coated wires were found to have a significant effect. The productivity and surface roughness were found to be better than uncoated wires. Several authors ${ }^{12-14}$ also suggested that the concentration of electrical discharges at a certain point of the wire, which causes an increase in the localized temperature, resulting in the breakage of the wire. V. Chengal Reddy et al. ${ }^{15}$ discussed the effects of the input control parameters, such as $T_{\mathrm{ON}}, T_{\mathrm{OFF}}$, Current, WT, upper flush and lower flush on the $\mathrm{R}_{\mathrm{a}}$, MRR and Kerf Width, while machining the aluminum HE 30 material and suggested the selection of the right combination of input parameters by Grey Relational Analysis (GRA).

Dain Thomas et al. ${ }^{16}$, developed a second-order regression model using RSM and found that $T_{\mathrm{ON}}$ and $W T$ play a major role in the surface roughness. V. R. Surya et al. ${ }^{17}$ predicted the machining characteristics of an $\mathrm{Al}$ 7075-TiB2 composite using ANN for the maximum MRR, minimum Dimensional Error (DE) and better surface finish. In this study the control factors considered were $T_{\mathrm{ON}}, T_{\mathrm{OFF}}$, Current and Bed Speed based on Taguchi's L 27 orthogonal array. S. Prashantha et al. ${ }^{18}$ investigated the Al 6061 aluminium alloy reinforced with $\mathrm{SiC}$ particles by varying the percentage of $\mathrm{SiC}$ from $3 \%$, $6 \%$ and $9 \%$ by weight. $T_{\mathrm{ON}}, T_{\mathrm{OFF}}$, Current (I) and Bed speed (BS) are varied to find their effects on the MRR. From the analysis, the average MRR for an unreinforced $\mathrm{Al} 6061$ aluminium alloy is $9.2 \mathrm{~mm}^{3} / \mathrm{min}$ and the average MRR is $9.15 \mathrm{~mm}^{3} / \mathrm{min}, 9.13 \mathrm{~mm}^{3} / \mathrm{min}$ and $9 \mathrm{~mm}^{3} / \mathrm{min}$, respectively for $\mathrm{Al} 6061$ aluminium alloy MMCs with $3 \%, 6 \%$ and $9 \% \mathrm{SiC}$, i.e., the MRR decreases with an increase of the silicon carbide particles. S. Prasad Arikatla et al. ${ }^{19}$ executed a study on a titanium alloy using RSM in WEDM and registered the quality of the machined surface by $T_{\mathrm{ON}} \&$ Input Power and WT \& SV. In the I case $\mathrm{Ra}$ increases while in the II case $\mathrm{Ra}$ decreases. G. Amitesh and K. Jatinder ${ }^{20}$ investigated the influence of machining parameters on the material removal rate and the cutting speed for the machining of Nimonic 80 A with Brass wire as the electrode in wire electrical discharge machining. From the observation, the cutting speed (CS) and MRR both increase with an increase in $T_{\mathrm{ON}}$ and the Peak Current (IP). Furthermore, it decreases with an increase in $T_{\mathrm{OFF}}$ and the spark gap set voltage. M. T. Antar et al. ${ }^{21}$ explored the role of coated wire in the production and surface integrity, while machining aerospace alloys in WEDM. Coated wires are stated to protect the core from thermal shock and also from wire rupture. Its other effects were found on vibration, damping effect, heat transfer and resistance, which ultimately increased the machining speed. N. Kinoshita et al..$^{22}$ observed that wire breaks due to a rapid rise in the pulse frequency of the gap voltage. They developed a monitoring and control system that switches off the pulse generator and the servo system, preventing the wire from breaking, but it affects the machining efficiency.

The above literature review indicates that most of the researchers have considered the influence of a limited 
Table 1: Al 7075 alloy composition in percentage by weight

\begin{tabular}{|c|c|c|c|c|c|c|c|c|c|}
\hline $\mathrm{Al}$ & $\mathrm{Cr}$ & $\mathrm{Cu}$ & $\mathrm{Fe}$ & $\mathrm{Mg}$ & $\mathrm{Mn}$ & $\mathrm{Si}$ & $\mathrm{Ti}$ & $\mathrm{Zn}$ & others \\
\hline $87.1-91.4$ & $0.18-0.28$ & $1.2-2.0$ & Max 0.5 & $2.1-2.9$ & Max 0.3 & Max 0.4 & Max 0.2 & $5.1-6.1$ & Max 0.15 \\
\hline
\end{tabular}

number of control parameters on the performance measures of Wire Electric Discharge Machined parts. Furthermore, from the literature review it is understandable that the impact of coated wires was found to improve the productivity and surface finish, better than uncoated wires. Hence, it is intended to investigate the effect of the selected variable process parameters on the surface roughness, while machining with zinc-coated copper wire of diameter $0.25 \mathrm{~mm}$. So far, no such investigation was carried out on the Al 7075 aluminium alloy. In this study an attempt has been made to optimize the various WEDM process parameters such as $T_{\mathrm{ON}}, T_{\mathrm{OFF}}$, $W F$ and $W T$ to find out the best fit to obtain minimum $R_{\mathrm{a}}$.

\section{EXPERIMENTAL PART}

\subsection{Work material}

As the Al 7075 Aluminium alloy is a lightweight material, zinc-based alloy and possesses excellent corrosion resistant, it is widely used in marine, aerospace applications and in the medical field. Aluminium alloys have very good mechanical properties such as a high tensile strength, a very high yield strength, good fatigue strength, and superior corrosion resistance, and average machinability. However, these alloys were very difficult to fabricate as they are not ductile and have a low fracture toughness at room temperature. An unconventional machining process like WEDM is used intensively for a better process The response is to machine an aluminium alloy, due to its exceptional strength properties, whereas it is very difficult to machine in a conventional method. The analysis of the consequence of different process parameters is essential.

\subsection{Machine tool}

WEDM requires thin, single-strand conducting metal wire that is used as the electrode. There are several electrode materials available, but brass wire is commercially used. The wire can either be coated wire (zinc, brass, tin, magnesium etc.) or uncoated wire (copper, brass, molybdenum). This conducting wire is passed through the pre-drilled hole in the metal piece to be machined. The wire is fed from a spool and held between upper and lower guides tha are made of diamond, and in turn it is finally controlled by CNC and moved in the X-Y plane. This allows the wire-cut EDM to be programmed to cut very intricate, delicate and complex shapes. By using a pump, dielectric fluid (Deionised Water) is continuously passed over the work piece to remove, clear and flush out the debris that is cut from the work piece. When a D.C. supply is attached to the circuit, thousands of spark discharges occur across the gap between the wire and the work piece, which increases the temperature and causes the melting of material, erosion and even vaporizing and thus removing the metal from the work piece. The removed fine material particles are carried away by the dielectric fluid circulating around it.

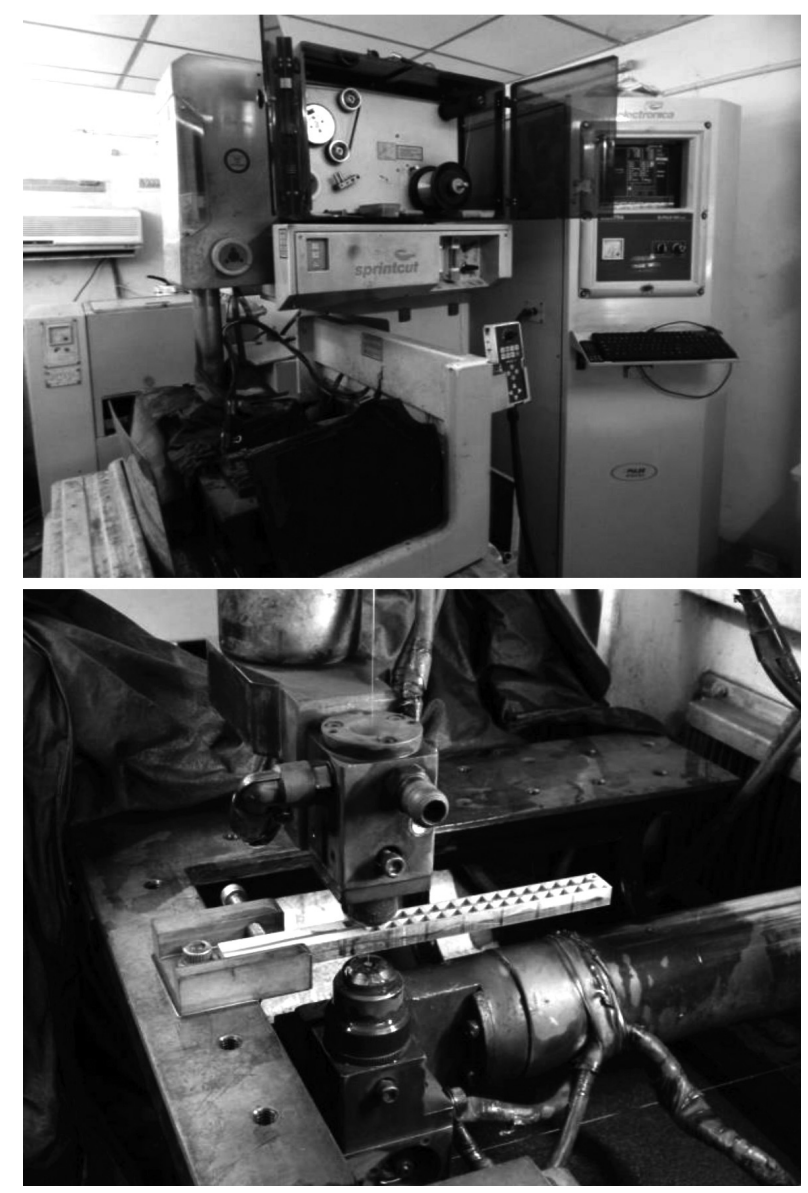

Figure 1: WEDM machine set up

Table 2: Properties of Al 7075 Aluminium Alloy

\begin{tabular}{|c|l|c|}
\hline Sl. No. & \multicolumn{1}{|c|}{ Property } & Value \\
\hline 1 & Density & $2.81 \mathrm{~g} / \mathrm{cc}$ \\
\hline 2 & Ultimate Tensile strength & $572 \mathrm{MPa}$ \\
\hline 3 & Tensile Yield strength & $503 \mathrm{Mpa}$ \\
\hline 4 & Elongation at break & $11 \%$ \\
\hline 5 & Modulus of Elasticity & $71.7 \mathrm{GPa}$ \\
\hline 6 & Poisson Ratio & 0.33 \\
\hline 7 & Hardness Brinell & 150 \\
\hline 8 & Fatigue strength & $159 \mathrm{MPa}$ \\
\hline 9 & Shear Modulus & $26.9 \mathrm{GPa}$ \\
\hline 10 & Machinability & 70 \\
\hline 11 & Thermal Conductivity & $477-635^{\circ} \mathrm{C}$ \\
\hline 12 & Melting Point & $5.15 \mathrm{e}^{-006} \Omega \mathrm{cm}$ \\
\hline 13 & Electrical Resistivity & \\
\hline
\end{tabular}



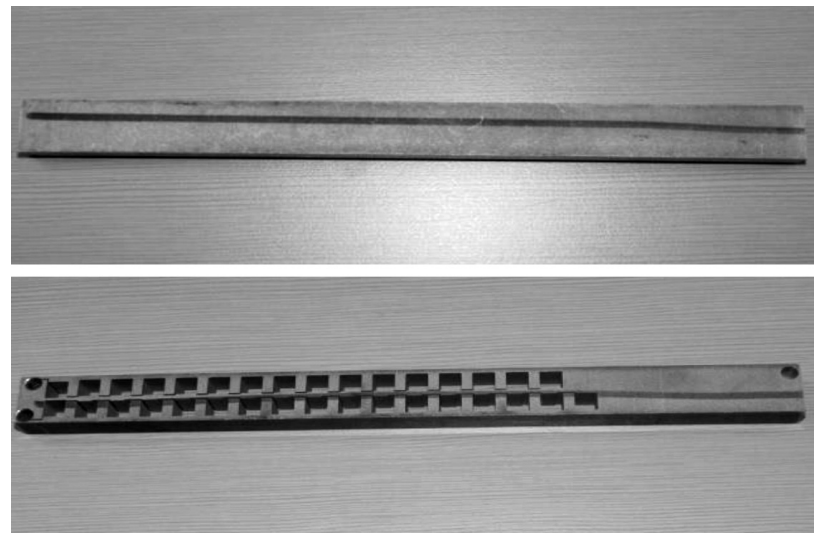

Figure 2: a) Work piece before machining and b) after machining

\subsection{Specimen}

An Al 7075 aluminum alloy rectangular block of length $200 \mathrm{~mm}$, width $16 \mathrm{~mm}$ and thickness $10 \mathrm{~mm}$ was taken as the work material. The experiment was performed on a WEDM machine with zinc-coated copper wire (tool) of $0.25 \mathrm{~mm}$ diameter and deionized water is used as the dielectric fluid.

\subsection{Parameters considered in this experiment}

Table 3: Fixed parameters

\begin{tabular}{|c|l|c|c|}
\hline Sl. No. & \multicolumn{1}{|c|}{ Parameter } & Unit & value \\
\hline 1 & Input Power & $\mathrm{V}$ & 230 \\
\hline 2 & $\begin{array}{l}\text { Dielectric fluid } \\
\text { pressure }\end{array}$ & $\mathrm{kg} / \mathrm{cm}^{2}$ & $\begin{array}{c}1 \text { machine unit } \\
\text { (low) }\end{array}$ \\
\hline 3 & Pulse Peak Voltage & $\mathrm{V}$ & 2 machine unit \\
\hline 4 & Servo Voltage & $\mathrm{V}$ & 20 \\
\hline 5 & Servo Frequency & cycles/s & 2100 \\
\hline
\end{tabular}

Table 4: Variable parameters and range

\begin{tabular}{|c|l|c|c|c|}
\hline S1. No. & \multicolumn{1}{|c|}{ Parameter } & Unit & From & To \\
\hline 1 & Pulse On $\left(T_{\text {ON }}\right)$ & $\mu s$ & 120 & 128 \\
\hline 2 & Pulse Off $\left(T_{\text {OFF }}\right)$ & $\mu s$ & 50 & 58 \\
\hline 3 & Wire Feed $(W F)$ & $\mathrm{m} / \mathrm{min}$ & 1 & 3 \\
\hline 4 & Wire Tension $(W T)$ & $\mathrm{N}$ & 5 & 9 \\
\hline
\end{tabular}

\subsection{Experimental values}

Table 5: Experimental results of $R_{\mathrm{a}}$ using $L 27$ orthogonal array matrix

\begin{tabular}{|c|c|c|c|c|c|c|c|c|}
\hline & \multicolumn{4}{|c|}{$\begin{array}{c}\text { Variable Process } \\
\text { Parameters } \\
\end{array}$} & \multicolumn{2}{|c|}{ Response $R_{\mathrm{a}}$} & \multirow[b]{2}{*}{ Error } & \multirow[b]{2}{*}{$\begin{array}{l}\mathrm{Re}- \\
\text { marks }\end{array}$} \\
\hline \multirow[t]{2}{*}{ S1. no. } & $\begin{array}{c}\text { Pulse } \\
\text { on }\end{array}$ & $\begin{array}{l}\text { Pulse } \\
\text { off }\end{array}$ & $\begin{array}{l}\text { Wire } \\
\text { Feed }\end{array}$ & $\begin{array}{l}\text { Wire } \\
\text { Ten- } \\
\text { sion }\end{array}$ & $\begin{array}{c}\text { Exper- } \\
\text { imen- } \\
\text { tal }\end{array}$ & $\begin{array}{l}\text { RSM } \\
\text { pre- } \\
\text { dicted }\end{array}$ & & \\
\hline & $\mu \mathrm{s}$ & $\mu \mathrm{s}$ & $\mathrm{m} / \mathrm{min}$ & $\mathrm{N}$ & $\mu \mathrm{m}$ & $\mu \mathrm{m}$ & $\%$ & \\
\hline 1 & 128 & 54 & 2 & 5 & 1.84 & 2.08 & 11.62 & \\
\hline 2 & 120 & 54 & 1 & 7 & 1.80 & 1.92 & 6.44 & \\
\hline 3 & 124 & 58 & 2 & 9 & 1.36 & 1.39 & 1.88 & WB \\
\hline 4 & 124 & 58 & 1 & 7 & 1.91 & 1.95 & 1.95 & \\
\hline 5 & 124 & 50 & 2 & 5 & 1.79 & 2.19 & 18.12 & \\
\hline 16 & 124 & 54 & 2 & 7 & 1.94 & 2.15 & 9.94 & \\
\hline 7 & 120 & 58 & 2 & 7 & 1.62 & 1.48 & 9.31 & \\
\hline
\end{tabular}

\begin{tabular}{|c|c|c|c|c|c|c|c|c|}
\hline 8 & 128 & 54 & 3 & 7 & 1.91 & 2.22 & 13.96 & \\
\hline 9 & 128 & 54 & 1 & 7 & 1.93 & 2.23 & 13.38 & \\
\hline 10 & 124 & 54 & 3 & 5 & 1.87 & 2.02 & 7.61 & \\
\hline 11 & 124 & 54 & 3 & 9 & 1.74 & 1.94 & 10.12 & \\
\hline 12 & 120 & 54 & 2 & 5 & 1.73 & 1.69 & 2.37 & \\
\hline 13 & 120 & 54 & 2 & 9 & 1.35 & 1.55 & 13.13 & \\
\hline 14 & 124 & 54 & 2 & 7 & 1.93 & 2.15 & 10.40 & \\
\hline 15 & 128 & 54 & 2 & 9 & 1.39 & 1.88 & 26.14 & WB \\
\hline 16 & 128 & 50 & 2 & 7 & 1.98 & 2.47 & 19.97 & \\
\hline 17 & 124 & 50 & 1 & 7 & 1.86 & 2.27 & 17.99 & \\
\hline 18 & 124 & 50 & 3 & 7 & 2.11 & 2.52 & 16.14 & \\
\hline 19 & 120 & 54 & 3 & 7 & 1.67 & 1.80 & 7.43 & \\
\hline 20 & 128 & 58 & 2 & 7 & 1.62 & 1.62 & 0.12 & \\
\hline 21 & 124 & 54 & 2 & 7 & 1.98 & 2.15 & 8.08 & \\
\hline 22 & 124 & 54 & 1 & 5 & 2.02 & 2.17 & 6.83 & \\
\hline 23 & 120 & 50 & 2 & 7 & 1.55 & 1.89 & 17.99 & \\
\hline 24 & 124 & 54 & 1 & 9 & 1.73 & 1.92 & 9.90 & \\
\hline 25 & 124 & 50 & 2 & 9 & 1.65 & 2.11 & 21.95 & \\
\hline 26 & 124 & 58 & 2 & 5 & 1.70 & 1.65 & 3.03 & WB \\
\hline 27 & 124 & 58 & 3 & 7 & 1.54 & 1.57 & 2.04 & \\
\hline
\end{tabular}

\subsection{Surface roughness}

Roughness is a measure of the texture (quality) of the surface. It is quantified by the vertical deviations of the actual surface from its ideal form. If these deviations are large, the surface is rough; if they are small, the surface is smooth. The surface roughness $R_{\mathrm{a}}$ was measured with a Mitutoyo Surftest 211 Surface Roughness tester and the values are tabulated in Table $\mathbf{5}$.

\subsection{Response Surface Methodology (RSM)}

This is a collection of statistical and mathematical techniques useful for developing, improving and optimizing processes. RSM consists of an experimental approach to investigate the independent variables in the process, the experimental statistical model developed for an appropriate similar relationship between the yield and the process variables. Optimization methods for finding values of the process variables that produce desirable values of the responses. In order to investigate the effects of the WEDM parameters on the above-mentioned machining criteria, second-order polynomial response surface mathematical models can be developed. In the general case, the response surface is described by an equation of the form:

$$
Y=\beta_{0}+\Sigma \beta_{\mathrm{j}} x_{\mathrm{j}}+\Sigma \beta_{\mathrm{jj}} x_{\mathrm{j}}^{2}+\Sigma \Sigma \beta_{\mathrm{ij}} x_{\mathrm{i}} x_{\mathrm{j}}
$$

where $\mathrm{Y}$ is the response, in current research surface roughness, whereas the terms $\beta_{0}, \beta_{\mathrm{j}}, \beta_{\mathrm{ij}}$ are second-order regression coefficients. The second term under the summation sign of this polynomial equation is attributable to a linear effect, whereas the third term corresponds to the higher-order effects and the fourth term of the equation includes the interactive effects of the process parameters. The above equation can be rewritten as:

$Y=\beta_{0}+\beta_{1} X_{1}+\beta_{2} X_{2}+\beta_{3} X_{3}+\beta_{4} X_{4}+\beta_{11} X_{12}+\beta_{22} X_{22}+$

$\beta_{33} X_{32}+\beta_{44} X_{42}+\ldots$. 
The value of $\beta$, the regression coefficient, will be determined by the least-squares method.

\subsection{Wire breakage}

A wide variety of the control strategies preventing the wire from breaking are based on a knowledge of the characteristics of the wire. The breaking of the wire can be due to the excessive thermal load producing unwarranted heat on the wire. Most of the thermal energy generated during the WEDM process is transferred to the wire, while the rest is lost to the flushing fluid. However, when the instantaneous energy rate exceeds a certain limit depending on the thermal properties of the wire material, the wire will break. The WB in the Table 5 indicates the occurrence of wire breakage while conducting the experiment, hence the corresponding set of parameters to be avoided for better performance.

\section{RESULTS}

\subsection{Response Surface Methodology (RSM)}

The relationship between the selected variable process parameters and the response $\mathrm{R}_{\mathrm{a}}$ was obtained by a quadratic regression equation using RSM in Minitab. This regression equation is useful in predicting the response surface roughness with respect to the variable process parameters Pulse on Time (A), Pulse off Time (B), Wire Feed (C) and Wire Tension (D).

$R_{\mathrm{a}}=-231.114+2.903 \mathrm{~A}+1.773 \mathrm{~B}+0.866 \mathrm{C}+1.162$ $\mathrm{D}-0.01 \mathrm{~A}^{2}-0.008 \mathrm{~B}^{2}+0.05 \mathrm{C}^{2}-0.048 \mathrm{D}^{2}-0.007$ $\mathrm{A} \cdot \mathrm{B}+0.007 \mathrm{~A} \cdot \mathrm{C}-0.002 \mathrm{~A} \cdot \mathrm{D}-0.039 \mathrm{~B} \cdot \mathrm{C}-0.006$ $\mathrm{B} \cdot \mathrm{D}-0.02 \mathrm{C} \cdot \mathrm{D}$

Figure 3 shows the difference between the experimental and predicted $R_{\mathrm{a}}$. The error percentage was calculated based on the input variable process parameters and the predicted value, and tabulated in Table 5, and found to be reasonable.

\subsection{Analysis of variance for $R_{a}$}

Table 6: ANOVA result for $R_{\mathrm{a}}$

\begin{tabular}{|c|c|c|c|c|c|}
\hline Source & DF & Seq SS & Adj MS & F & $\begin{array}{c}\% \text { Contri- } \\
\text { bution }\end{array}$ \\
\hline Regression & 14 & 1.02098 & 0.072927 & 15.96 & \\
\hline Linear & 4 & 0.45663 & 0.057484 & 12.58 & \\
\hline Pulse on & 1 & 0.07521 & 0.175001 & 38.31 & 6.99 \\
\hline Pulse off & 1 & 0.11801 & 0.132032 & 28.90 & 10.97 \\
\hline Wire Feed & 1 & 0.01401 & 0.002568 & 0.56 & 1.30 \\
\hline Wire Tension & 1 & 0.24941 & 0.018231 & 3.99 & 23.18 \\
\hline Square & 4 & 0.40138 & 0.100344 & 21.97 & \\
\hline $\begin{array}{c}\text { Pulse on* } \\
\text { Pulse on }\end{array}$ & 1 & 0.07993 & 0.140833 & 30.83 & 7.43 \\
\hline $\begin{array}{c}\text { Pulse off* } \\
\text { Pulse off }\end{array}$ & 1 & 0.05184 & 0.083333 & 18.24 & 4.82 \\
\hline $\begin{array}{c}\text { Wire Feed* } \\
\text { Wire Feed }\end{array}$ & 1 & 0.07707 & 0.133333 & 2.92 & 7.16 \\
\hline
\end{tabular}

\begin{tabular}{|c|c|c|c|c|c|}
\hline $\begin{array}{l}\text { Wire Tension* } \\
\text { Wire Tension }\end{array}$ & 1 & 0.19253 & 0.192533 & 42.15 & 17.90 \\
\hline Interaction & 6 & 0.16297 & 0.027162 & 5.95 & \\
\hline $\begin{array}{l}\text { Pulse on* } \\
\text { Pulse off }\end{array}$ & 1 & 0.04623 & 0.027162 & 10.12 & 4.30 \\
\hline $\begin{array}{l}\text { Pulse on* } \\
\text { Wire Feed }\end{array}$ & 1 & 0.00302 & 0.046225 & 0.66 & 0.28 \\
\hline $\begin{array}{c}\text { Pulse on* } \\
\text { Wire Tension }\end{array}$ & 1 & 0.00122 & 0.003025 & 0.27 & 0.11 \\
\hline $\begin{array}{l}\text { Pulse off* } \\
\text { Wire Feed }\end{array}$ & 1 & 0.09610 & 0.001225 & 21.04 & 8.93 \\
\hline $\begin{array}{c}\text { Pulse off* } \\
\text { Wire Tension }\end{array}$ & 1 & 0.01000 & 0.096100 & 2.19 & 0.93 \\
\hline $\begin{array}{c}\text { Wire Feed* } \\
\text { Wire Tension }\end{array}$ & 1 & 0.00640 & 0.010000 & 1.40 & 0.59 \\
\hline Residual Error & 12 & 0.05482 & 0.006400 & & \\
\hline Lack-of-Fit & 10 & 0.05342 & 0.004568 & 7.63 & \\
\hline Pure Error & 2 & 0.00140 & 0.005342 & & \\
\hline Total & 26 & 1.07580 & 0.000700 & & \\
\hline
\end{tabular}

\subsection{Contribution of the process variable parameter during machining}

Table 6 shows the results of the ANOVA for a $95 \%$ confidence level of $R_{\mathrm{a}}$. It is observed from the table that foremost variable that affects $R_{\mathrm{a}}$ is linear $W T$ with a contribution of $23.18 \%$. The second important factor is squared WT with a contribution of $17.90 \%$, then linear $T_{\mathrm{OFF}}$ with $10.97 \%$, interaction of $T_{\mathrm{OFF}} \times W F$, squared $T_{\mathrm{ON}}$, squared $W F$, linear $T_{\mathrm{ON}}$, squared $T_{\mathrm{OFF}}$, interaction of $T_{\mathrm{ON}} \times$ $T_{\mathrm{O} \text { FF }}$ and linear $W F$, with a contribution of $(8.93,7.43$, $7.16,6.99,4.82,4.30$ and 1.30$) \%$ respectively. In addition to the above, it is found that interaction of $T_{\mathrm{OFF}} \times$ $W T, W F \times W T, T_{\mathrm{ON}} \times W F, T_{\mathrm{ON}} \times W T$ contribution values are less than $1 \%$, which states that these interactions do not affect $R_{\mathrm{a}}$. Further, from Table 5, it is observed that the predicted values from RSM are close to the experimental values of $R_{\mathrm{a}}$. The higher correlation coefficient $\left(R^{2}\right)$ of more than $90 \%$ confirms the fitness of the model.

Figure 4a shows the fitness of the experimental $R_{\mathrm{a}}$ obtained to the predicted $R_{\mathrm{a}}$. It is observed that there is not much deviation found between the experimental value and the predicted value obtained from RSM. Fig-

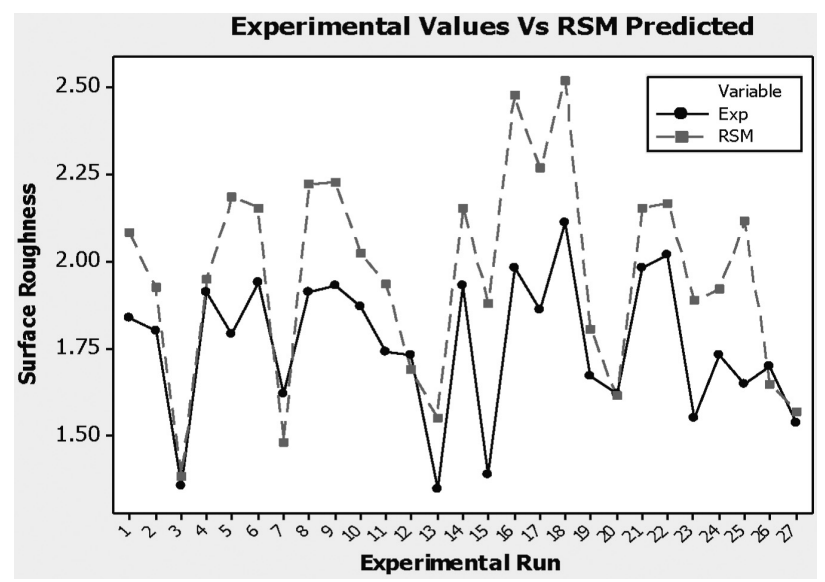

Figure 3: Experimental vs. predicted values of $R_{\mathrm{a}}$ 


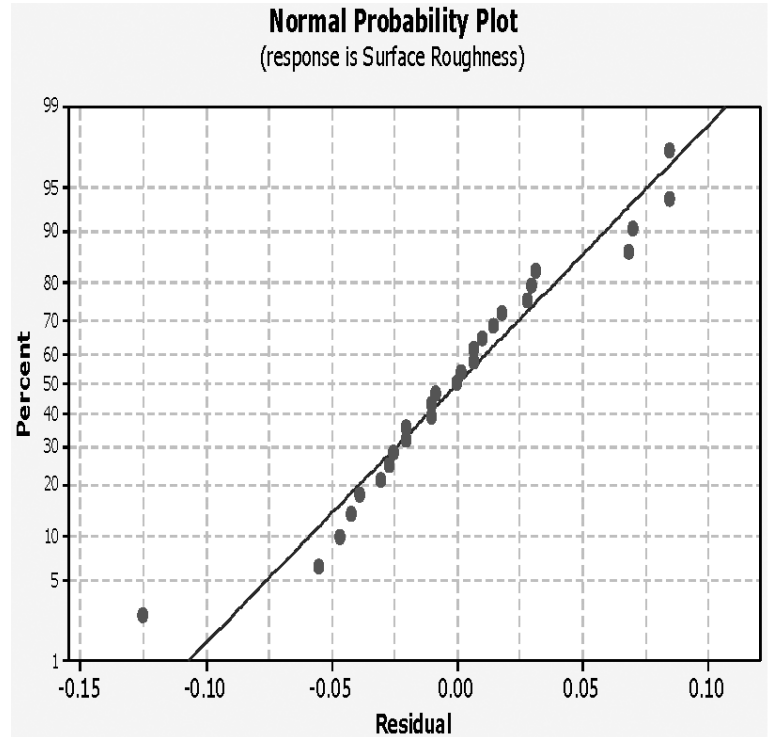

Figure 4: a) Fitness of the experiment, b) effect of $S N$ ratios

ure $4 \mathbf{b}$ shows the effect plot for the $\mathrm{SN}$ ratios of the data mean of $R_{\mathrm{a}}, R_{\mathrm{a}}$ is the minimum for the minimum $T_{\mathrm{ON}}$, maximum $T_{\mathrm{OFF}}$, moderate $W F \&$ maximum $W T$. $R_{\mathrm{a}}$ is the maximum for mid-value $T_{\mathrm{ON}}$, minimum $T_{\mathrm{OFF}}$, minimum $W F$ and $W T$.

\subsection{Contour and surface plots of RSM}
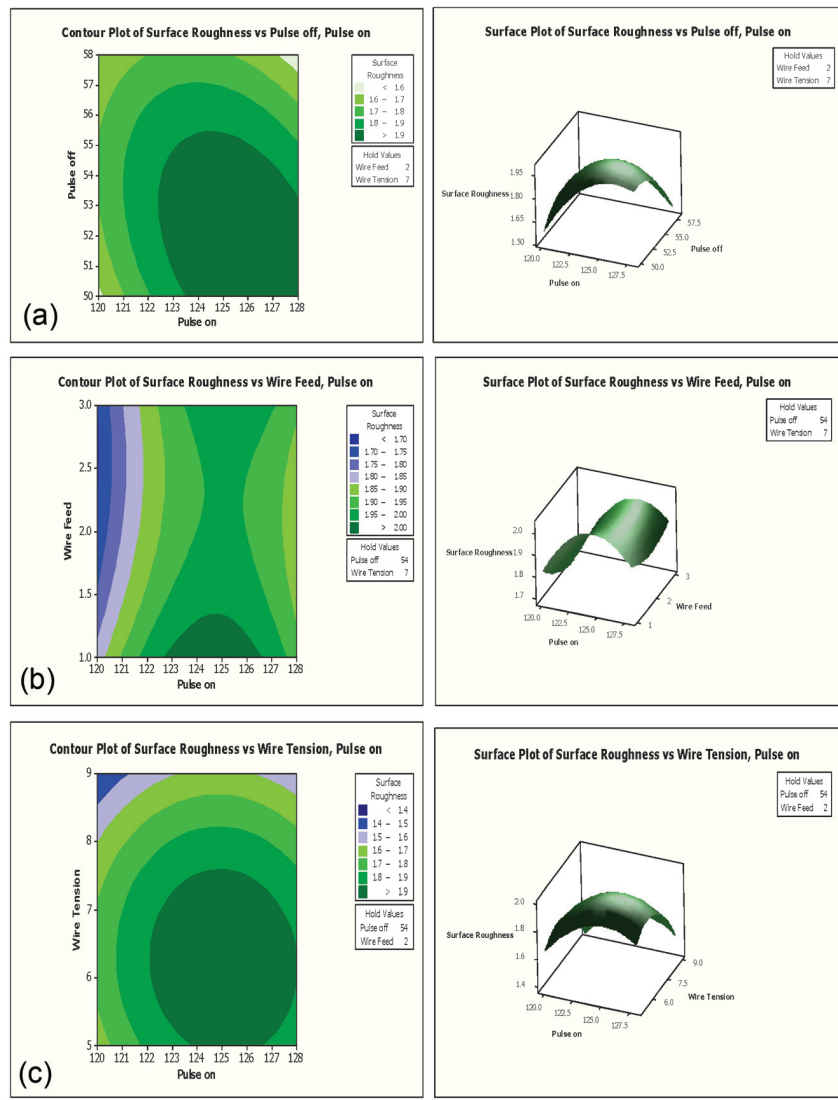

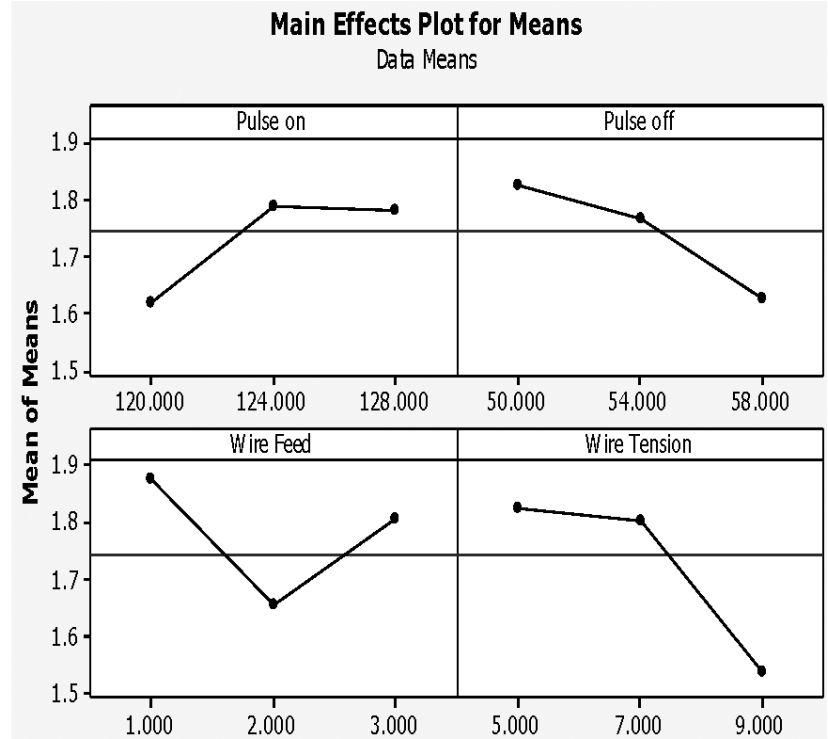

\section{DISCUSSION}

\subsection{Discussion of contour plot and surface plot ob- tained from RSM}

Figure 5a depicts the effect of $T_{\mathrm{ON}}$ and $T_{\mathrm{OFF}}$ on $R_{\mathrm{a}}$ when $W F$ and $W T$ are held constant, for the $T_{\mathrm{ON}}$ value ranging from $123.5 \mu \mathrm{s}$ to $128 \mu \mathrm{s}$ and $T_{\mathrm{OFF}}$ rate from $50 \mu \mathrm{s}$
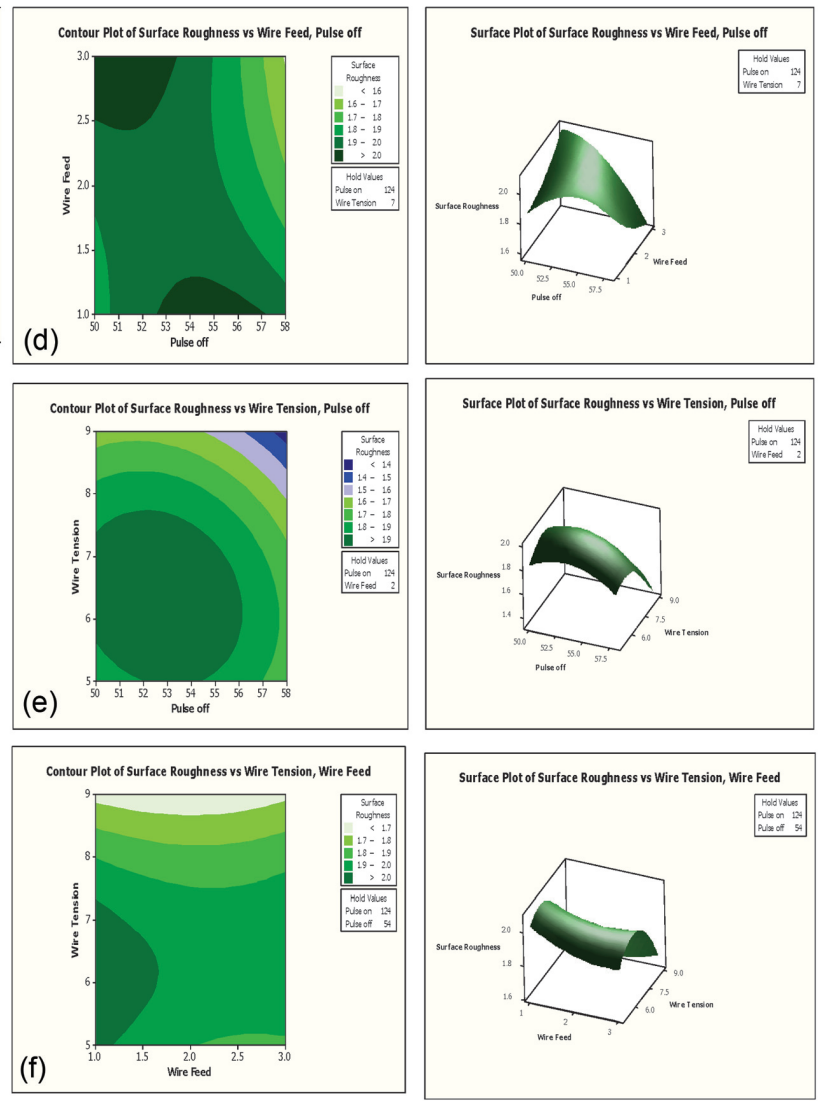

Figure 5: Contour plot and surface plot of surface roughness: a) $R_{\mathrm{a}}$ versus $T_{\mathrm{OFF}}, T_{\mathrm{ON}}$, b) $R_{\mathrm{a}}$ versus $\left.W F, T_{\mathrm{ON}}, \mathrm{c}\right) R_{\mathrm{a}}$ versus $W T, T_{\mathrm{ON}}$, d) $R_{\mathrm{a}}$ versus $W F, T_{\mathrm{OFF}}$, e) $R_{\mathrm{a}}$ versus $W T, T_{\mathrm{OFF}}$, f) $R_{\mathrm{a}}$ versus $W T, W F$ 
to $54.5 \mu \mathrm{s}$, the $R_{\mathrm{a}}$ value is a maximum $(>1.90 \mu \mathrm{m})$. There is a gradual increase in the $R_{\mathrm{a}}$ for the intermediate $T_{\mathrm{OFF}}$ value and lower for higher and lower $T_{\mathrm{OFF}}$ value, as the $T_{\mathrm{ON}}$ value decreases the $R_{\mathrm{a}}$ value also decreases. And for the $T_{\mathrm{ON}}$ value ranging from $120 \mu$ s and $T_{\mathrm{OFF}}$ value $50 \mu \mathrm{s}$, the $R_{\mathrm{a}}$ value is a minimum $(<1.60 \mu \mathrm{m})$.

Figure $5 \mathbf{b}$ depicts the effect of $T_{\mathrm{ON}}$ and $W F$ on $R_{\mathrm{a}}$ when $T_{\mathrm{OFF}}$ and $W T$ are held constant, for the $T_{\mathrm{ON}}$ value ranging from $122.5 \mu$ s to $126.5 \mu$ s and for the $W F$ value ranging between $1 \mathrm{~m} / \mathrm{min}$ and $1.25 \mathrm{~m} / \mathrm{min}$, the $R_{\mathrm{a}}$ value is a maximum $(>2.00 \mu \mathrm{m})$, hence this condition should be avoided. As the $\mathrm{T}_{\mathrm{ON}}$ value decreases and $W F$ increases simultaneously the $R_{\mathrm{a}}$ value decreases. For the $T_{\mathrm{ON}}$ value of $120 \mu \mathrm{s}$ and the $W F$ range from $2.5 \mathrm{~m} / \mathrm{min}$ to $3.0 \mathrm{~m} / \mathrm{min}$, the $R_{\mathrm{a}}$ value is a minimum $(<1.7 \mu \mathrm{m})$. This is the ideal condition.

Figure 5c depicts the effect of $T_{\mathrm{ON}}$ and $W T$ on $R_{\mathrm{a}}$ when $T_{\mathrm{OFF}}$ and $W F$ are held constant, for the value of $T_{\mathrm{ON}}$ ranging from $122.5 \mu$ s to $128 \mu$ s and for $W T$ value $5 \mathrm{~N}$ to $7 \mathrm{~N}$, the $R_{\mathrm{a}}$ value is a maximum $(>1.9 \mu \mathrm{m})$, for the $T_{\mathrm{ON}}$ rate $120 \mu$ s to $121.5 \mu$ s and $W T$ values from $8.5 \mathrm{~N}$ to $9 \mathrm{~N}$, the $R_{\mathrm{a}}$ value is a minimum $(<1.4 \mu \mathrm{m})$. As the $T_{\mathrm{ON}}$ value decreases and $W T$ value increases simultaneously, the $R_{\mathrm{a}}$ values decreases further for selected low $T_{\mathrm{ON}}$ value and high $W T$ value the $R_{\mathrm{a}}$ value is found to be a minimum.

Figure $5 \mathbf{d}$ depicts the effect of $T_{\mathrm{OFF}}$ and $W F$ on $R_{\mathrm{a}}$ when $T_{\mathrm{ON}}$ and $W T$ are held constant, the $R_{\mathrm{a}}$ value is a maximum ( $>2.0 \mu \mathrm{m}$ ) for a $T_{\mathrm{OFF}}$ value of $50 \mu \mathrm{s}$ to $53 \mu \mathrm{s}$ and $W F$ value above $2.5 \mathrm{~m} / \mathrm{min}$, i.e., in general it is clear that for minimum $T_{\mathrm{OFF}}$ value and maximum $W F$ value the $R_{\mathrm{a}}$ is a maximum. For a $T_{\text {OFF }}$ of more than $58 \mu$ s and $W F$ value of $3.0 \mathrm{~m} / \mathrm{min}$, the $R_{\mathrm{a}}$ is minimum $(<1.6 \mu \mathrm{m})$ and for the other values of $T_{\mathrm{OFF}} \& W F$, the $\mathrm{R}_{\mathrm{a}}$ value is medium.

Figure 5e depicts the effect of $T_{\mathrm{OFF}}$ and $W T$ on $R_{\mathrm{a}}$ when $T_{\mathrm{ON}}$ and $W F$ are held constant, it is observed that for the $T_{\mathrm{OFF}}$ value ranging from $50 \mu$ s to $56 \mu$ s and $W T$ value ranging from $5.5 \mathrm{~N}$ to $7.5 \mathrm{~N}$, the $R_{\mathrm{a}}$ value is a maximum $(>1.9 \mu \mathrm{m})$, the Surface Roughness will be in the extreme condition, and for $T_{\mathrm{OFF}}$ value exceeding $57.5 \mu$ s and $W T$ value exceeding $8.7 \mathrm{~N}$, the $R_{\mathrm{a}}$ value is a

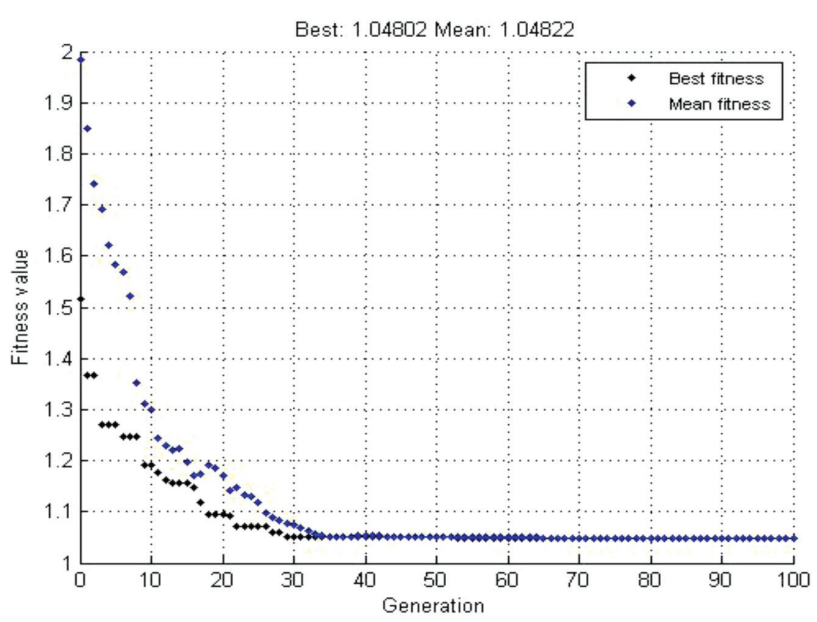

Figure 6: Predicted optimal solution of $R_{\mathrm{a}}$ using GA minimum $(<1.4 \mu \mathrm{m})$. As the $T_{\mathrm{OFF}}$ and $W T$ increases simultaneously the $R_{\mathrm{a}}$ value decreases.

Figure 5f depicts the effect of $W F$ and $W T$ on $R_{\mathrm{a}}$ when $T_{\mathrm{ON}}$ and $T_{\mathrm{OFF}}$ are held constant. When the $W F$ ranges from $1 \mathrm{~m} / \mathrm{min}$ to $1.75 \mathrm{~m} / \mathrm{min}$ and $W T$ values ranges from $5 \mathrm{~N}$ to $7.3 \mathrm{~N}$, the $R_{\mathrm{a}}$ value is a maximum $(>2.0 \mu \mathrm{m})$ the Surface Roughness will be in the excessive, which is an adverse condition. For the all values of $W F$ and $W T$ the value exceeding $8.8 \mathrm{~N} R_{\mathrm{a}}$ is a minimum $(<1.7 \mu \mathrm{m})$, as $W T$ increases $R_{\mathrm{a}}$ decreases.

\subsection{Simulation results obtained from the genetic algo- rithm}

The equation obtained from RSM, i.e., Equation (3), is used for the minimization of $R_{\mathrm{a}}$ by using GA in MATLAB software to find the optimal selected variable process parameters for the best fit $R_{\mathrm{a}}$ values. Where $T_{\mathrm{ON}}$, $T_{\mathrm{OFF}}, W F$ and $W T$ are 4 variables, the population size selected for this simulation is 100 , the Rank is set as the Fitness Scaling Function, Stochastic uniform is set as the Selection Function, the Reproduction elite count is 2, the Cross over probability is 0.8 , the Cross over function is scattered, the Mutation probability is 0.05 , the Initial penalty is 10 , the Iteration is 100 , the Number of generations is 100, and the Stopping criteria is Best Fitness.

The optimization function is formulated as

Minimize $R_{\mathrm{a}}\left(T_{\mathrm{ON}}, T_{\mathrm{OFF}}, W F, W T\right)$

Subject to the following condition:

$120 \mu \mathrm{s} \leq T_{\mathrm{ON}} \geq 128 \mu \mathrm{s}$

$50 \mu \mathrm{s} \leq T_{\mathrm{OFF}} \geq 58 \mu \mathrm{s}$

$1 \mathrm{~m} / \mathrm{min} \leq W F \geq 3 \mathrm{~m} / \mathrm{min}$

$5 \mathrm{~N} \leq W T \geq 9 \mathrm{~N}$

Figure 6 depicts the best optimal solution for the Surface Roughness obtained in the simulation, for the input value of $T_{\mathrm{ON}}-120 \mu \mathrm{s}, T_{\mathrm{OFF}^{-}}-58 \mu \mathrm{s}, W F-3 \mathrm{~m} / \mathrm{min}$, $W T-9 \mathrm{~N}$ the best fit Predicted $R_{\mathrm{a}}$ Value is $1.048 \mu \mathrm{m}$.

\subsection{Confirmation experiment}

Confirmatory experiments carried out for the input value of $T_{\mathrm{ON}} 120 \mu \mathrm{s}, T_{\mathrm{OFF}} 58 \mu \mathrm{s}, W F 3 \mathrm{~m} / \mathrm{min}$, WT $9 \mathrm{~N}$ and the experimental $R_{\mathrm{a}}$ value obtained is $1.08 \mu \mathrm{m}$ and the error percentage between the predicted and experimental value is calculated as 3.05, which is less than $5 \%$. It confirms the excellent reproducibility of the results. Table 7 indicates the error obtained.

Table 7: Comparison of the Optimized Process Parameter and its best fit $R_{a}$ value

\begin{tabular}{|c|c|c|}
\hline Sl. no. & Parameter & Values \\
\hline 1 & Pulse On $\left(T_{\mathrm{ON}}\right)$ & $120 \mu \mathrm{s}$ \\
\hline 2 & Pulse Off $\left(T_{\mathrm{OFF}}\right)$ & $58 \mu \mathrm{s}$ \\
\hline 3 & Wire Feed $(W F)$ & $3 \mathrm{~m} / \mathrm{min}$ \\
\hline 4 & Wire Tension $(W T)$ & $9 \mathrm{~N}$ \\
\hline $\begin{array}{c}\text { Best Fit } R_{\mathrm{a}} \text { Value } \\
\text { (Predicted) } \mu \mathrm{m}\end{array}$ & 1.048 \\
\hline $\begin{array}{c}\text { Actual } R_{\mathrm{a}} \text { Value } \\
(\text { Experimental) } \mu \mathrm{m}\end{array}$ & 1.08 \\
\hline Error $\%$ & 3.05 \\
\hline
\end{tabular}




\section{CONCLUSIONS}

The present work elucidates the effect of variable WEDM process parameters while machining an Al 7075 alloy is investigated by using zinc-coated copper wire, a quadratic model for the Surface Roughness was developed, using RSM, to correlate the effects of the process parameters and the same is used in GA to establish the best fit $R_{\mathrm{a}}$. Based on the results obtained the following conclusions were furnished for machining of an Al 7075 alloy using zinc-coated copper wire.

The best fit Surface Roughness value predicted is $1.048 \mu \mathrm{m}$ for Pulse On $\left(T_{\mathrm{ON}}\right)$ value $120 \mu \mathrm{s}$, Pulse Off $\left(T_{\mathrm{OFF}}\right)$ value $58 \mu \mathrm{s}$, Wire Feed $(W F) 3 \mathrm{~m} / \mathrm{min}$ and for Wire Tension (WT) value $9 \mathrm{gm}$.

It is observed that for the increase in the Pulse On time, the Surface Roughness also increases.

The Surface Roughness decreases as the Pulse Off time increases.

The increase in the Wire Tension leads to a decrease of the Surface Roughness.

Wire Feed does not influence much on the Surface Roughness.

For the maximum value of Pulse Off $\left(T_{\mathrm{OFF}}\right)$, Wire Feed $(W F)$, the Wire Tension (WT) and minimum Pulse On $\left(T_{\mathrm{ON}}\right)$ the Surface Roughness predicted is a minimum, which is the ideal condition for improving the quality of machined parts.

Furthermore, WEDM can be employed for machining an Al 7075 alloy with other coated and uncoated wires in order to compare the machined surfaces.

\section{REFERENCES}

${ }^{1}$ G. E. Totten, D. S. Mackenzie, Handbook of Aluminium [M]//Vol 1, Physical metallurgy and processes, Marcel Dekker, New York and Basel 2003

${ }^{2}$ J. Prohaszka, A. G. Mamalis, N. M. Vaxevanidis, The effect of electrode material on machinability in wire electro-discharge machining, J Mater Process Technol, 69 (1997) 233-237, doi:10.1007/s00170016-9598-9

${ }^{3}$ R. Chalisgaonkar, J. Kumar, Investigation of the machining parameters and integrity of the work and wire surfaces after finish cut WEDM of commercially pure titanium, Brazilian Society Mechanical Science and Engineering (2015), doi:10.1007/s40430015-0335-3

${ }^{4}$ B. Sivaraman, C. Eswaramoorthy, E. P. Shanmugham, Optimal control parameters of machining in CNC Wire-Cut EDM for Titanium, Int. Journal of Applied Sciences and Engineering Research, 4 (2015) 1, doi:10.6088/ijaser.04011

${ }^{5}$ G. Selvakumar, G. Sornalatha, S. Sarkar, S. Mitra, Experimental investigation and multi-objective optimization of wire electrical discharge machining (WEDM) of 5083 aluminum Alloy, Transaction of Nonferrous Metals Society of China 24 (2014) 373-379, doi:org/10.1016/S1003-6326(14)63071-5

${ }^{6}$ D. Siva Prasad, C. Shoba, K. Rahul Varma, A. Khurshid, Influence of wire EDM parameters on the damping behaviour of A 356.2 aluminum Alloy, Journal of Alloys and Compounds (2015), doi:10.1016/j.jallcom.2015.06.050
${ }^{7}$ A. Dey, S. Debnath, K. M. Pandey, Optimization of electrical discharge machining process parameters for A16061/Cenosphere composite using grey-based hybrid approach, Transaction of Nonferrous Metals Society of China, 27 (2017), 998-1010, doi:10.1016/S1003-6326(17)60117-1

${ }^{8}$ K. H. Ho, S. T. Newman, S. Rahimifard, R. D. Allen, State of the art in wire electrical discharge machining (WEDM), International Journal of Machine Tools \& Manufacture, 44 (2004), 1247-1259, doi:10.1016/j.ijmachtools.2004.04.017

${ }^{9}$ Shajan Kuriakose, M. S. Shunmugam, Multi-objective optimization of wire-electro discharge machining process by Non-Dominated Sorting Genetic Algorithm, Journal of Materials Processing Technology, 170 (2005), 133-141, doi:10.1016/j.jmatprotec.2005.04.105

${ }^{10}$ A. Sharma, M. Pal Garg, K. Kumar Goyal, Prediction of optimal conditions for WEDM of Al 6063/ ZrSiO4 (p) MMC, Procedia Materials Science, 6 (2014), 1024-1033, doi:10.1016/j.mspro.2014. 07.173

${ }^{11}$ H. C. Tsai, B. H. Yan, F. H. Huang, EDM performance of $\mathrm{Cr} / \mathrm{Cu}$ based composite electrodes, International Journal of Machine Tools \& Manufacturing, 43 (2003) 3, 245-252, doi:10.1016/j.matpr. 2015.07.328

${ }^{12}$ K. Shoda, Y. Kaneko, H. Nishimura, M. Kunieda, M. X. Fan, Adaptive control of WEDM with on-line detection of spark locations, Proc. of the Tenth International Symp. for Electro-Machining (ISEM-10), Magdeburg 1992

${ }^{13}$ M. Kunieda, H. Kojima, N. Kinoshita, On-line detection of EDM spark location by multiple connection of branched electric wires, Ann. CIRP 39 (1) (1990) 171-174, doi:10.1016/S0007-8506(07) 61028-2

${ }^{14}$ T. Tanimura, C. J. Heuvelman, P. C. Vennstra, The properties of the servo gap sensor with wire spark-erosion machining, Ann. CIRP 26 (1) (1977) 59-63

${ }^{15}$ V. Chengal Reddy, N. Deepthi, N. Jayakrishna, Multiple response optimization of wire EDM on aluminium HE30 by using grey relational analysis, Materials Today: Proc. 2, 2015, 2548-2554, doi:10.1016/j.matpr.2015.07.201

${ }^{16}$ D. Thomas, R. Kumar, G. K. Singh, P. Sinha, S. Mishra, Modelling of surface roughness in coated wire electric discharge machining through response surface methodology, Materials Today: Proc. 2, 2015, 3520-3526, doi:10.1016/j.matpr.2015.07.091

${ }^{17}$ V. R. Surya, K. M. Vinay Kumar, R. Keshavamurthy, G. Ugrasen, H. V. Ravindra, Prediction of machining characteristics using artificial neural network in wire EDM of Al 7075 based in-situ composite, Materials Today: Proc. 4 (2017), 203-212, doi:10.1016/j.matpr. 2017.01.014

${ }^{18}$ S. Prashantha, R. B. Veeresha, S. M. Shashidhara, U. S. Mallikarjun, A. G. Shivasiddaramaiah, A study on machining characteristics of Al 6061-Sic metal matrix composite through wire - cut electro discharge machining, Materials Today: Proc. 4 (2017), 10779-10785, doi:10.1016/j.matpr.2017.08.027

${ }^{19}$ S. Prasad Arikatla, K. TamilMannan, Arkanti Krishnaiah, Parametric optimization in wire electrical discharge machining of titanium alloy using response surface methodology, Materials Today: Proc. 4, (2017), 1434-1441, doi:10.1016/j matpr 2241-7853

${ }^{20} \mathrm{G}$. Amitesh \& K. Jatinder, An investigation into the machining characteristics of NIMONIC 80A using CNC wire EDM, International Journal of Advanced Engineering Technology, 3 (2012) 1, 170-174

${ }^{21}$ M. T. Antar, S. L. Loo, D. K. Aspinwall, Productivity and work piece surface integrity when WEDM aerospace alloys using coated wires, Journal of Procedia engineering (2011)

${ }^{22}$ N. Kinoshita, M. Fukui, G. Gamo, Control of wire-EDM preventing electrode from breaking, Ann. CIRP 311 (1982), 111-114, doi:10.20965/ijat.2014.p0468 